Japanese Women Entrepreneurs: Implications for Family Firms

By: Dianne H.B. Welsh, Esra Memili, Eugene Kaciak, Miyuki Ochi

This is the accepted version of the following article:

Welsh, D. H. B., Memili, E., Ouchi, M., \& Kaciak, E. (2014). Japanese Women Entrepreneurs: Implications for Family Firms. Journal of Small Business Management, 52(2), 286-305. doi:10.1111/jsbm.12099,

which has been published in final form at http://dx.doi.org/10.1111/jsbm.12099

****Reprinted with permission. No further reproduction is authorized without written permission from Wiley. This version of the document is not the version of record. Figures and/or pictures may be missing from this format of the document. $* * *$

\begin{abstract}
:
Japanese women entrepreneurs and their predominately family-owned firms are a growing economic segment in Japan. The number of entrepreneurs of both genders in Japan is proportionately very small compared to other countries. The purpose of this research is to investigate the characteristics of Japanese women entrepreneurs and their family firms, identify barriers and resources that affect their success. A customized long-term support system with strong connections between family business supporters and women business owners by both the governmental and private agencies was identified as important for further growth of Japanese women entrepreneurs. Implications are discussed.
\end{abstract}

Keywords: Business | Entrepreneurs | Japan | Women | Gender Roles | Family Business

Article:

\title{
Introduction
}

Women entrepreneurs are growing worldwide in developed as well as emerging economies. Especially when it comes to Small and Medium-Sized Enterprises (SMEs), women predominate (Hadary 2010; The World Bank 2012). A vast majority of these women-owned businesses are family businesses. Though this is a growing segment of the economy, little research has been done on this population although it is well documented in the popular press worldwide (Hadary 2010; Hall 2004; Hutcheson and Zimmerman 2007; Jordan 2004; Leon 2012; Murphy et al. 2003; Pope 2002; "Woman-Owned Family Business" 2003; "Women to Watch" 2004) and to a limited extent in Japan (Fulford 2004a, 2004b; Schoenberger 2008). What little research that exists on the role of family involvement in businesses in international research has been inconsistent (Sciascia et al. 2012). 
According to the Global Entrepreneurship Monitor Women's Report (GEM), over 100 million women in 59 countries launched and grew a new business venture in 2010 (Kelly et al. 2011). These countries represent more than 52 percent of the world's population and 84 percent of the world's gross domestic product (GDP). Women entrepreneurs comprise 1.5 percent to 45.4 percent of the adult female population in their respective economies, and over 80 million women across those regions ran businesses that they had launched at least $31 / 2$ years previously (Kelly et al. 2011). Together, these approximately 180 million women exemplify the contributions made by women to entrepreneurship around the globe (Kelly et al. 2011). The GEM Report gave limited information on Japanese women entrepreneurs, reporting that only 3 percent of Japanese women are in the early stages of developing their business compared with 6 percent of men (Kelly et al. 2011).

Japan is considered to be one of the least entrepreneurial countries in the world, whereas it is one of the most innovation-driven economies, and also strongly patriarchal. Given the patriarchal culture, it makes sense that Japanese men are starting businesses at about double the rate of Japanese women entrepreneurs (Kelly et al. 2011). Japanese conventional business culture, the seniority system, enterprise unions, lifetime employment schemes with mutual loyalty between both employees and employers, and restrictive government policies account for Japanese society's slow growth into new venture creation (Futagami and Helms 2009; Sugihara and Katsurada 2002). It is well documented that high levels of entrepreneurial activity are related to increases in GDP, societal wealth, and quality of life (Futagami and Helms 2009). Nevertheless, Japan is aware of the need to progress into an entrepreneurial society and is slowly trying to make progress in this area despite its traditional views on the role of women in society and that it is considered a patriarchal society (Hofstede 2001).

Given the importance of context (e.g., family) in entrepreneurship (Hughes et al. 2012; Welter 2011; Zahra 2007), we draw upon the family embeddedness perspective (Aldrich and Cliff 2003), to investigate Japanese women entrepreneurs and their businesses, their unique characteristics, family support and personal problems they face, and the interplay between these two in influencing firm performance. We also provide recommendations for success based on the results of our study. Three principal research questions addressed in our empirical analysis are: (1) How does family support affect Japanese women entrepreneurs' firm performance, (2) How do personal problems affect Japanese women entrepreneurs' firm performance, and (3) How are the combined effects of family support and personal problems affect Japanese women entrepreneurs' firm performance?

We begin with an overview of women entrepreneurs in Japan and family embeddedness perspective. Then, we develop our hypotheses and present our methodology. We also provide a discussion of findings and implications for future research, practice, and policymaking. 


\section{Women Entrepreneurs in Japan}

\section{History}

Research on women entrepreneurs in Japan is limited and encompasses mostly information on women entrepreneurs in agricultural districts. Even the history of Japanese women entrepreneurs is not yet clearly defined. The latest statistics show 1,063,000 women entrepreneurs and 4,847,000 male entrepreneurs (The Japanese Ministry of Internal Affairs and Communications 2007). The number of women entrepreneurs in Japan has, in fact, been decreasing since the 1990s (Takahashi 2002). As the world's third largest economy behind the United States and China, this trend is unusual. Internationally, Japan is characterized by low levels of entrepreneurial activity predominated by men (Baughn, Chua, and Neupert 2006). Japanese perceived capabilities, opportunity perception, and entrepreneurial intentions about the female adult population are extremely low (Kelly et al. 2011). Even if the number of Japanese women entrepreneurs is decreasing, their development prior to the 1980s to the present has changed. This progress can be explained from two different perspectives: focusing on women themselves as entrepreneurs and emphasizing changes in the industrial structure (Tamura 2002).

The rise of women in the labor force is a crucial factor relating to women as entrepreneurs. The Annual Report on Working Women (The Japanese Ministry of Economy, Trade, and Industry 2010) shows that 27,680,000 women were working in Japan in 2010. This number accounted for 42 percent of the labor force, the highest percentage since the report started. However, though the male-dominated traditional economic system still persists in Japan, women are a vital part of the business world now (Brown and Oakland 2007). Many are involved in the fields of medicine, welfare, direct sales, manufacturing, travel, and food (The Japanese Ministry of Economy, Trade, and Industry 2010). Tamura (2002), and Moore and Buttner (1997) point out that women who have work experience may decide to launch new businesses after they face barriers with predominant female stereotyping as part of the company culture. The opportunity to attain higher education may also contribute to this increase in women-owned businesses (Tamura 2002).

Another factor contributing to the change in market structure is the industrial structure changing from heavy industries to service industries since World War II. Moreover, growth of the Internet and information technology has enabled women to create businesses around this technology (Futagami and Helms 2009; Tamura 2002). The development of technology has led women to develop home-based businesses. In addition, as more women are working, their purchasing power has grown making them the primary consumers. This trend has also motivated women to start new businesses (Tamura 2002).

\section{Characteristics}

The Japanese Ministry of Health, Labour, and Welfare began publishing an official Annual Report on Japanese Women Entrepreneurs in 2010 that reveals previously unknown 
characteristics of women entrepreneurs. The Ministry had long published a report on male entrepreneurs. The report found that 30.2 percent of women entrepreneurs run service businesses, followed by direct sales at 18 percent, and 17.2 percent of women entrepreneurs owning food and travel businesses (The Japanese Ministry of Internal Affairs and Communications 2007).

In addition to service occupations, women primarily start solo businesses. Japan is not an exception; many women around the world tend to create small, medium-sized businesses, launching their businesses with a limited amount of money, spending money they already have, or acquiring funds from their support groups, primarily family and friends (Tamura 2002; Welsh 2012). Most businesses have a few employees (Oishi 2002). We found the same results so far in our studies of women-owned businesses in Romania, Saudi Arabia, and the Sudan (Welsh 2012; Welsh and Memili 2012).

The Annual Report on Japanese Women Entrepreneurs (2010) shows that women become entrepreneurs at a younger age than men. The average age for male entrepreneurs is 39.9 years, whereas women average around 35.5 years when they start a business in Japan (The Japanese Ministry of Economy, Trade, and Industry 2010). This compares with the United States, where the average age of men is 40 and women is 41 when starting a business (Chung 2012). It is possible that women start a new business as a way of reemployment, not only because of the desire to earn more money or to manage their own business, but rather for the chance to run a business based on their own interests or to meet their individual goals in life (Oishi 2002; Tamura 2002; The Japanese Ministry of Economy, Trade, and Industry 2010). This implies that women may start a business for their own self-accomplishment as well as creating an income. This could partly explain why women who are younger than their male colleagues can face the challenges of launching a new business. Additionally, the fact that there are greater expectations in Japan for men to enter the corporate world while women find they face the "glass ceiling" leads many women to start their own businesses. This also may be a response to raising a family and wanting a career and income at the same time. Traditional industry in Japan has been set up as an either/or proposition for women-career or family, but not both.

Leung (2011) calls the relationship between entrepreneurship and motherhood as one of Japan's unique characteristics. It is difficult to discuss Japanese women's gender identity without mentioning the ideal woman, dutiful wife, and nurturing mother (ryosaikenbo in Japanese). Leung (2011) finds that the "identity of motherhood can serve as the propellant for women and that gender role identity can become the defining element of the venture identity and be a significant resource leading to a competitive advantage in female entrepreneurship" (p. 261). However, this competitive advantage is being lost due to societal norms and expectations. According to recent National Institute of Population and Social Security Research survey findings summarized in a Bloomberg Businessweek news article (2012, p. 16), "70\% respondents said mothers should stop work to focus on raising children." Bloomberg Businessweek also reports that although Japan is at the top of "the list of 144 countries for innovation capacity in 
World Economic Forum's latest Global Competitiveness Report, it placed $87^{\text {th }}$ for women's participation in the labor force, the second lowest after Italy, among Group of Seven developed economies" (p. 16).

\section{Barriers}

Although the number of women entrepreneurs is growing and contributing to jobs and wealth in many societies (Brush et al. 2010), the latest GEM Report finds that entrepreneurship declines as economic development levels increase. Countries with innovation-driven economies, such as Japan, tend to have competitive environments and a concentration of knowledge-based businesses, whereas countries with factor-driven economies have more necessity-based and consumer-oriented entrepreneurs (Kelly et al. 2011). Women face many challenges - personal, professional, and societal - that may contribute to avoidance of risk-taking and the challenges of starting a new business that may contribute to why starting up a new business is more difficult for women than men (Carter et al. 2007).

A major problem for Japanese women is the lack of knowledge and skills in business management. The Annual Report on Japanese Women Entrepreneurs (2010) found that the average age of women who start a business is quite young. Because many women may leave their jobs before they have job training at the management level, it may be more difficult for women to develop managerial skills.

Obtaining financing is another problem for female entrepreneurs in Japan (Takahashi 2002; The Japanese Ministry of Economy, Trade, and Industry 2010). Takahashi (2002) found that Japanese women encountered difficulties in acquiring funding through financial institutions. However, there are no statistics available on financial capital for entrepreneurs by gender. Some researchers say this does not seem to be an issue anymore for Japanese women. The upward trend on the availability of capital for women entrepreneurs can also be observed in other developed countries, including the United States (Greene et al. 2001).

\section{Support}

Lack of essential entrepreneurial support systems is a major issue. Though support for improving women's lives and self-realization are basic support systems guaranteed by the government, women need entrepreneurship and business education, job training, networking opportunities, and household support, including childcare (The Japanese Ministry of Economy, Trade, and Industry 2010). Unfortunately, due to the lack of research on women entrepreneurs, the government says it does not have the evidence to justify new policies to create these essential support systems (Takahashi 2002). The government must provide substantial funding for research on women entrepreneurs to encourage researchers to engage in this research and SME business development to impact public policy.

\section{Family Support}


Consistent with research highlighting the importance of investigating the context in entrepreneurship studies (e.g., Hughes et al. 2012; Welter 2011; Zahra 2007), we examine Japanese women entrepreneurs within the context of family support and personal issues, determining their firm performance. We draw upon the "family embeddedness" perspective (Aldrich and Cliff 2003, p. 573) as a substantial number of small businesses across countries tend to exhibit family involvement either through family's involvement in governance or providing support to the entrepreneur family member (Chang et al. 2009). Indeed, families and businesses are not separate institutions and are rather intertwined (Aldrich and Cliff 2003).

Following Aldrich and Cliff's (2003) family embeddedness perspective and call for studies investigating how family dynamics affect entrepreneurial processes, Chang et al. (2009) examine how family support affects venture preparation and creation among Hispanic entrepreneurs in New England in the United States. The authors find that family support in the forms of resources and encouragement positively affects both venture preparation and venture start-up. This is in line with unified systems approach provided by Habbershon, Williams, and MacMillan (2003). Habbershon, Williams, and MacMillan (2003) suggest that family, business, and individual family members interact to generate idiosyncratic antecedents to firm performance. Indeed, success through prosperity of new ventures through the appropriate use of resources is also as critical as venture preparation and creation (Sharma 2008).

However, according to Uzzi $(1996,1997)$, embeddedness process by which social relationships shape economic action can be paradoxical, leading to both positive and negative consequences. Overembeddedness can decrease the flow of new information and hinder adaptation. Social expectations may supersede economic imperatives, strong assumptions of trust and cooperation may be exploited, and the focus on the quality of transactions can be shifted toward quality of relationships (Uzzi 1997).

In line with Uzzi's $(1996,1997)$ concerns regarding embeddedness, family business researchers (e.g., Sharma 2008; Smith 2009; Steier 2003; Steier, Chua, and Chrisman 2009) also draw attention to the positive as well as negative impact of embeddedness in family firms. Sharma (2008) highlights the importance of balanced flow of resources between family and firm, which can lead to stocks of unique resources. However, the author also states that there can be an imbalance and negative spillovers from one system to the other can occur. Accordingly, Smith (2009, p. 1239) presents the "rights" of family membership notion, which is common in East Africa unlike some Western cultures, where family membership endows family members with many rights such as the right to have residual claim over a family business regardless of the contribution or input level of them. Smith (2009) also suggests that this tends to generate many free-riders within the domain of family businesses. What is even more interesting is that those family businesses hire outsiders to monitor and control opportunistic behaviors of family members. 
In Western cultures, family members may exhibit both selfless altruistic and selfish market rationalities among family members when multiple family members are involved in a business (Steier 2003). On the one side, family members are supportive and nurturing of each other. On the other side, they may also have selfish market related (e.g., profitability) concerns and expectations. What makes family relations more complex is the multiple and shifting rationalities among family members (Steier 2003).

It is likely that Japanese women entrepreneurs may rely on family support just like many other entrepreneurs around the world. However, we do not know enough about the impact of family dynamics in Japanese women entrepreneurs' new ventures. In an attempt to have a better understanding regarding this phenomenon, we examine the impact of family support in the form of moral and financial support on firm performance in the following sections.

\section{Hypotheses}

\section{Japanese Women Entrepreneurs' Family Support and Firm Performance}

When external support systems for women entrepreneurs are limited because of cultural biases against entrepreneurship, preference for life-long employment at well-established larger firms, and expected primary gender roles as being a mother and spouse (Hinz 2004; Ohe, Honjo, and MacMillan 1990; Sugihara and Katsurada 2002), family support for venturing may be particularly valuable for Japanese women entrepreneurs. A recent study by Chang et al. (forthcoming) suggests that family involvement can provide support elements in terms of resources, encouragement, norms and values, and social capital as well as networks for venture creation and success (Aronoff and Ward1995; Chang et al. 2009; Habbershon and Williams 1999; Hoffman, Hoelscher, and Sorenson 2006; Pearson, Carr, and Shaw 2008; Sundaramurthy and Kreiner 2008). Accordingly, past research has also drawn attention to the positive influence of family members in the strategic management process (e.g., Chrisman, Chua, and Steier 2005). Family members tend to exhibit altruistic and nurturing behaviors (Steier 2003), such as mentoring and guidance (Arregle et al. 2007), that can positively contribute to the business start-up and successful management activities in new ventures. Furthermore, family members may provide entrepreneur(s) with the use of the family's finances

(e.g., seed money) or help in obtaining external funding sources (Aldrich and Cliff 2003; Anderson, Jack, and Dodd 2005; Dyer and Handler 1994). Additionally, family members can provide necessary labor and help that can be used at all stages of venture start-up and success (Dyer 2003; Karra, Tracey, and Phillips 2006; Teixeira 2001). Indeed, family members represent important resources to women entrepreneur(s), particularly to the ones who may lack access to other networks during the venture development process (Greve and Salaff 2003). This type of support can be even more valuable when family members have an entrepreneurship background, because those members become role models and mentors to aspiring entrepreneurs not only during the venture preparation process but also during the business creation process (Aldrich and Cliff 2003; Chang et al. 2009; Minniti and Bygrave 1999; Shapero and Sokol 1982). Moreover, 
family members may be altruistically involved with the entrepreneur(s) and the venture (Arregle et al. 2007) owing to a feeling of obligation and responsibility toward kin (Karra, Tracey, and Phillips 2006), which can increase their willingness to help. Because family support can potentially be a valuable resource for entrepreneurs, we suggest that family support in the form of financial and moral support will be positively influential on Japanese women entrepreneurs' firm performance.

- H1: Family support in the form of moral and financial support is positively related to firm performance.

\section{Personal Problems}

The negative impact of personal problems (e.g., stress) on individuals' work performance is well documented in the literature (e.g., Cropanzano, Rupp, and Byrne 2003; Pflanz and Ogle 2006). Because small business owner-managers play the key role in their businesses' success or failure and their personal problems may be even more severe owing to their tendency to wear several hats at work (Glackin 2002; Hall 2004), we expect that Japanese women entrepreneurs' personal problems will be influential on firm performance.

When Japanese women entrepreneurs face issues (e.g., emotional stress and loneliness), they may not be able to focus on multiple tasks they may be responsible for and commit themselves to their businesses because they need to devote their time, energy, and resources to resolve these issues. These can prevent Japanese women entrepreneurs from effective decision-making and actions, which can harm firm performance. Hence:

- H2: Personal problems are negatively related to Japanese women entrepreneurs' firm performance.

\section{Interaction Effects of Family Support and Personal Problems}

Within the framework of family embeddedness perspective suggesting both bright and dark sides of family embeddedness (Sharma 2008; Smith 2009; Steier, Chua, and Chrisman 2009), we also expect that when combined with personal problems, the positive impact of family support on firm performance can become negative. In a recent study, Memili, Zellweger, and Fang (2013) demonstrate that harmonious and supportive families may have higher expectations concerning family responsibilities. The authors also suggest that family members may attach more salience to family when there is harmony and support and having to meet higher family expectations may place more pressure and guilt on a family business owner-managers when faced with challenges at work. When high family expectations are not met, harmonious and supportive family members may react relatively more harshly than less harmonious family members owing to feelings of betrayal of trust, exacerbating the negative impact of personal problems and diminishing the positive impact of family support on firm performance. Hence, supportive families' elevating the negative impact of personal problems on firm performance may be more acute. 
Indeed, when family is influential on the business through moral and financial support, although this can be beneficial to the firm itself, it can also elevate the ability, authority, and power of family members to interfere with the business in case of Japanese women entrepreneurs' personal problems. This problem may be even more acute in businesses owned by Japanese women entrepreneurs owing to patriarchal cultural norms and women's expected gender roles and loyalty, submissiveness, and obedience toward spouses and seniors in the family (Sugihara and Katsurada 2002). This can exacerbate the negative effects of personal problems on firm performance, outweighing the independent positive effects of family support.

- H3: Personal problems negatively moderate the relationship between family support and firm performance such that the interaction effect of family support and personal problems on firm performance will be negative.

We test our hypotheses and present the results in the following Methodology section.

\section{Methodology}

\section{Sample}

A self-administered questionnaire adapted from Hisrich, Bowser, and Smarsh (2006) was utilized. The 27 questions were translated into Japanese, and three items related to family business were added. Data collection took place in Japan from February to September of 2012 using online surveys and personal contact with business organizations throughout Japan. One of the researchers spoke to business organizations about the study in person and urged members to complete the online survey. Of the 128 women who responded to the survey, 101 women entered responses to the qualitative questions for a response rate of 78 percent. Respondents ranged from 20 and 59 years. The largest age group is $40-49$ years old, accounting for 39 percent of the participants, followed by 50-59 years ( 24 percent), and 30-39 years old (14 percent). Fifteen percent of the participants are over 60 years of age and 8 percent of the respondents are 20-29 years old.

Twenty-four percent of women reported their businesses as a family business. Their businesses are relatively new and mostly were comprised of first- or second-generation family members. In addition, the respondents tended to start the business by themselves rather than with their family members regardless of whether their business would be classified as a family business or nonfamily business. Though it was reported that Japanese women generally start businesses not only for profit but for self-fulfillment (Oishi 2002; Tamura 2002; The Japanese Ministry of Economy, Trade, and Industry 2010), our results found that respondents are purposefully growing their businesses but are currently small with 56 percent having less than 10 employees and 38 percent did not have any employees. None of the respondents had more than 50 employees. 
The majority of women started their businesses locally and remain solely domestic businesses. Only two women ( 2 percent) started their business internationally, and eight women ( 7 percent) now are operating internationally. The vast majority of business owners ( 91 percent) own more than 50 percent of their business. Of those business owners, 79 percent started their business by themselves; only a few started the business with their spouse or family members. Thirty-one percent of women business owners construct their budget annually and 31 percent construct it according to demand. Possibly due to the type of business, Japanese women business owners are separated into two groups: 17 percent of respondents have a long range plan, whereas 14 percent have a seasonally adjusted plan.

\section{The Variables}

\section{Dependent Variable}

The dependent variable is a firm's performance (Firm Performance), measured through current annual income (Appendix Q27). We coded this variable as a dichotomy $=1$ when income is above the Japanese average (about $3.5 \mathrm{mln}$ JPY) and $=0$ when it is below it.

\section{Independent Variables}

Family Support: Our family support measure includes moral (from spouse, child, parent, siblings and/or relative; Appendix Q15) and financial (family borrowing-Appendix Q7, starting business with spouse or with another family member, buying or inheriting business from a family member; Appendix Q6). We used this measure initially designed to measure altruism to capture the support of family members (Becker and Vance 1993). Unlike Chang et al.'s (2009) measure of family support by adapting four items from Becker and Vance's (1993) measure of altruism, we only adapted the family moral support item as well as family financial support considering the limitations in external support resources of Japanese women entrepreneurs.

Personal Problems is based on a categorical variable measuring women's biggest personal problems during the establishment and running of their businesses - (1) the presence of any combination of emotional stress, family stress, loneliness, influence of business on family relationships, influence of business on personal relationships, poor or lack of support, loneliness, time management, dealing with males and/or dealing with drivers (Appendix Q21), and (0) the absence of any of such problems.

\section{Control Variables}

We controlled for two demographical factors owing to their potential impact on the dependent variables that are pertaining to perceptions (Rutherford and Holt, 2007; Stewart, May, and Kalia 2008):

Marital status indicates whether the respondent is either (1) married or (2) not married (single, separated, divorced, or widowed)—Appendix Q23. 
Age is a categorical variable measured at two levels: (1) 39 years old or less, (2) 40 or more years old (Appendix Q18).

The choice of the cut-off levels for the demographic variables' categories was based on theoretical considerations and their frequency distributions. We also controlled for Family Business Ownership = 1 (Yes); = 0 (No)-Appendix Q28.

\section{Analyses}

To examine the relationships among the dependent, independent, and control variables in our study, and to test our hypotheses, we conducted four binary logistic regressions. The choice of the binary logistic regression analysis was dictated by the binary nature of the dependent variable. Our approach was based on the moderation analysis procedures suggested by Baron and Kenny (1986) and Aiken and West (1991). In Model 1, we tested the relationship between the control variables and the dependent variable. In Model 2, we introduced the independent variable of family support. In Model 3, we added the hypothesized moderating variable for personal problems. Finally, in Model 4, we added the interaction of family support and personal problems.

The study design is depicted in Figure 1, descriptive data including zero-order correlations are presented in Table 1, and the results of the four binary logistic regressions are found in Table 2.

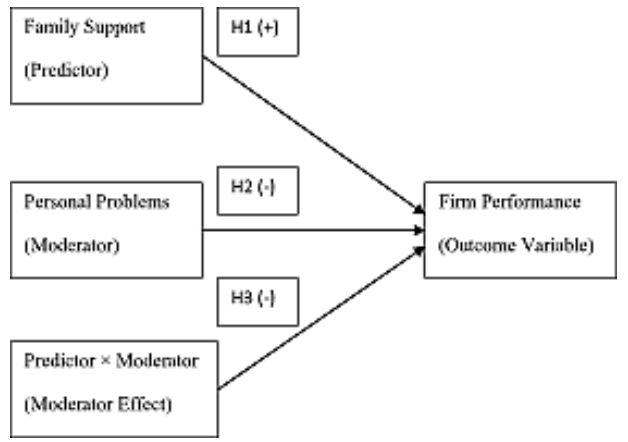

Figure 1. The Study Design

Table 1. Means, Standard Deviations, and Correlations

$\begin{array}{llllllll}\text { Mean } & \begin{array}{l}\text { Std. } \\ \text { Deviation }\end{array} & N & 1 & 2 & 3 & 4 & 5\end{array}$

1. Firm

Performance

2. Entrepreneur's

Age
$0.22 \quad 0.417$

$95 \quad 0.240^{*}$ 
$\begin{array}{llllllll}\text { Mean } & \begin{array}{l}\text { Std. } \\ \text { Deviation }\end{array} & N & 1 & 2 & 3 & 4 & 5\end{array}$
3. Marital Status
$\begin{array}{ll}0.68 & 0.467\end{array}$
$95-0.145$
$-0.303^{* * *}$

-
4. Family
Business
$0.24 \quad 0.427$
$89 \quad 0.002$
$-0.042$
$0.254^{*}-$
Ownership

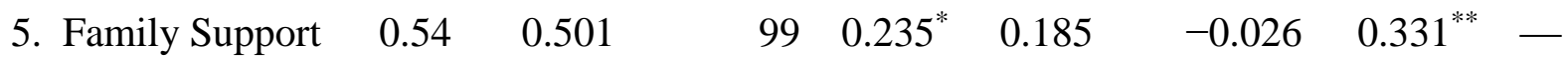
6. Personal
Problems
$0.33 \quad 0.471$
$92 \quad-0.049 \quad 0.203$
$-0.227^{*}-0.091 \quad 0.236^{*}$
*Correlation is significant at the 0.05 level (2-tailed).
**Correlation is significant at the 0.01 level (2-tailed).

Table 2. Logistic Regression Results

Model 1

Model $2 \quad$ Model $3 \quad$ Model 4

$N=\mathbf{8 0} \quad N=\mathbf{8 0} \quad N=\mathbf{8 0} \quad N=\mathbf{8 0}$

Control variables:

Age (1 = Younger;

$0=$ Older)

$1.062^{*}(0.591) \quad 0.799(0.615) \quad 0.878(0.627) \quad 1.101^{*}(0.660)$

Marital Status

$(1=$ Married;

$0=$ Unmarried)

$-0.387$

$(0.568)$

$-0.379(0.587) \quad-0.499(0.601) \quad-0.301(0.621)$

Family Business

Ownership (1 = Yes; $\quad 0.221(0.591) \quad-0.247(0.636) \quad-0.512(0.677) \quad-0.894(0.763)$

$0=\mathrm{No}$ )

Independent variables: 


\begin{tabular}{|c|c|c|c|c|}
\hline \multirow{2}{*}{$\begin{array}{l}\text { Model } 1 \\
N=\mathbf{8 0}\end{array}$} & \multirow{2}{*}{$\begin{array}{l}\text { Model } 2 \\
N=80\end{array}$} & \multirow{2}{*}{$\begin{array}{l}\text { Model } 3 \\
N=80\end{array}$} & \multicolumn{2}{|l|}{ Model 4} \\
\hline & & & $N=\mathbf{8 0}$ & \\
\hline \multicolumn{3}{|l|}{ Family Support } & $1.468^{* *}(0.605)$ & $2.425^{* * * *}(0.769)$ \\
\hline \multicolumn{2}{|l|}{ Personal Problems } & \multirow{2}{*}{$\begin{array}{l}1.138^{* *}(0.552) \\
(\mathrm{H} 1: \\
\text { confirmed) }\end{array}$} & $-0.952(0.596)$ & $1.060(0.953)$ \\
\hline $\begin{array}{l}\text { Family } \\
\text { Support } \times \text { Personal } \\
\text { Problems }\end{array}$ & & & $\begin{array}{l}\text { (H2: not } \\
\text { confirmed) }\end{array}$ & $\begin{array}{l}-2.975^{* *}(1.211) \\
(\mathrm{H} 3: \text { confirmed })\end{array}$ \\
\hline -2 Log Likelihood & 101.534 & 97.096 & 94.345 & 88.338 \\
\hline Cox and Snell $R^{2}$ & 0.064 & 0.114 & 0.144 & 0.206 \\
\hline Nagelkerke $R^{2}$ & 0.087 & 0.155 & 0.196 & 0.280 \\
\hline Model $\chi^{2}$ & 5.285 & $9.723^{* *}$ & $12.474^{* *}$ & $18.481^{* * *}$ \\
\hline df & 3 & 4 & 5 & 6 \\
\hline $\begin{array}{l}\text { Hosmer and Lemeshow } \\
\chi^{2}\end{array}$ & $\begin{array}{l}1.403 \\
(p=.705)\end{array}$ & $\begin{array}{l}3.276 \\
(p=.774)\end{array}$ & $6.313(p=.504)$ & $2.237(p=.946)$ \\
\hline \multicolumn{5}{|c|}{$\begin{array}{l}\text { Dependent variable: Firm Performance }(1=\text { High; } 0=\text { Low }) \\
\text { Independent variables: } \\
\text { Family Support }(1=\text { Yes; } 0=\text { No }) \\
\text { Personal Problems }(1=\text { Yes } 0=\text { No })\end{array}$} \\
\hline
\end{tabular}

Analysis of correlation coefficients did not indicate any issues of multicollinearity. Nevertheless, we further tested more formally for the unwanted presence of multicollinearity and calculated variance inflation factors (VIFs) for the control, independent, and moderator variables utilizing the GRETL software program and its binary logistic regression option. The VIFs were all below 3 thus suggesting no apparent problems with collinearity - values of VIF exceeding 10 are usually regarded as indicating multicollinearity but in weaker models, such as in logistic regression, value above 2.5 may be a cause for concern (Allison 1999). 


\section{Results}

In Model 1 (Table 2), we regressed the dependent variable (firm performance) on the three control variables (the female entrepreneur's age, her marital status, and family business ownership) in order to examine whether they had any influence on the relationships we theorized in our hypotheses. We found the entrepreneur's age to be statistically significantly (albeit weakly; $p=.072$ ) related to firm performance in the following way: younger women entrepreneurs (no more than 39 years old) are more likely to achieve better firm performance than those more mature entrepreneurs who are 40 or more years old. Overall, Model 1 was not significant $\left(\chi^{2}=5.285, p=.152\right)$; however, the Hosmer-Lemeshow goodness-of-fit test produced a desirable $(p>.05)$ outcome $\left(\chi^{2}=1.403, p=.705\right)$, indicating that the model prediction does not significantly differ from the observed. A $-2 \log$ likelihood value was 101.534 and pseudo$R^{2}$ values ranged from 0.064 (Cox and Snell $R^{2}$ ) to 0.087 (Nagelkerke $R^{2}$ ).

In Model 2, we tested our first hypothesis H1 that family moral and financial support is positively related to firm performance. For this purpose, we added to the three control variables our independent variable, family support. The binary logistic regression yielded a statistically significant and positive coefficient of the independent variable with respect to family support thus confirming H1. Model 2 was overall significant $\left(\chi^{2}=9.723, p=.045\right)$ and the HosmerLemeshow test produced an additional desirable result of nonsignificance $\left(\chi^{2}=3.276, p=.774\right)$. We also observed a wanted significant drop of the $-2 \log$ likelihood value from 101.534 to $97.096\left(\chi^{2}=4.438, p<.05\right)$ and a needed increase of Cox and Snell and Nagelkerke pseudo$R^{2}$ values to 0.114 and 0.155 , respectively.

Our next hypothesis, $\mathrm{H} 2$ (that personal problems are negatively related to Japanese women entrepreneurs' firm performance), was tested in Model 3, which was obtained from Model 2 by adding a moderator variable, personal problems. However, this newly added variable did not turn out to be significant $(p=.110)$, although its coefficient was negative as expected. Thus, personal problems alone have no statistically significant effect on firm performance. In Model 3, the -2 $\log$ likelihood value was further decreased by $\chi^{2}=2.751(p<.10)$ to 94.345 and the model remained significant $\left(\chi^{2}=12.474, p=.029\right)$. The Hosmer-Lemeshow test continued to produce desirable nonsignificance $\left(\chi^{2}=6.313, p=.504\right)$ and the pseudo- $R^{2}$ values further increased to 0.144 and 0.196 , respectively.

Finally, our last hypothesis, H3, was tested with the full moderator model (Model 3) with the moderator effect Family Support $\times$ Personal Problems. We hypothesized that personal problems negatively moderate the relationship between family support and firm performance such that the interaction effect of family support and personal problems on firm performance will be negative. The outcome did provide support for our hypothesis. In Model 4, the $-2 \log$ likelihood value was further decreased to $88.338\left(\chi^{2}=6.007, p<.01\right)$ and the model remained significant $\left(\chi^{2}=18.481, p=.005\right)$. The Hosmer-Lemeshow test continued to produce desirable 
nonsignificance $\left(\chi^{2}=2.237, p=.946\right)$ and the pseudo- $R^{2}$ values further increased to 0.206 and 0.280 , respectively.

Concerning the control variables, age continued to be statistically significantly related to the dependent variable in all four models. However, neither marital status nor family business ownership was found to be significantly related to firm performance.

\section{Discussion}

In response to a recent call for a richer understanding of women entrepreneurs around the world (Hughes et al. 2012) with considerations for different social and institutional contexts (Welter 2011; Zahra 2007), we examine the impact of family support, personal problems, and the interaction effects of family support and personal problems on Japanese women entrepreneurs' firm performance through the lens of family embeddedness perspective. Findings show that family support has positive effects on firm performance, as we expected. Interestingly, the hypothesized negative impact of personal problems on firm performance was not significant. This may be because of Japanese women entrepreneurs' ability to manage their personal problems so that these problems do not harm their businesses. However, when family support and personal problems are combined, they have significant negative effects on firm performance, as we hypothesized. This is in line with the paradox of embeddedness (Steier, Chua, and Chrisman 2009; Uzzi 1997), which may be owing to family's interfering with the business when Japanese women entrepreneurs face personal problems. Providing moral and financial support to women entrepreneurs may elevate family expectations and family members may presume power and authority to interfere with the business. Our findings are consistent with Welter (2011) suggesting that context can be both an asset and a liability at the same time for entrepreneurship.

\section{Limitations and Future Research}

This survey is a convenience sample conducted online and mostly through support organizations and networks of women entrepreneurs. Therefore, the results are strongly influenced by people who can use the Internet and belong to networking organizations. Even though the Japanese population has a high technological skill level, women use the Internet less than men (Futagami and Helms 2009). Future studies should include in the sample women entrepreneurs who do not use the Internet on a regular basis. Other means to gather data should also be included, such as student-based businesses, university technology transfer businesses that are began by women, representative samples throughout Japan in rural and urban environments, and matched genderbased samples. As most of the businesses owned by Japanese women entrepreneurs are family firms, future research can investigate other family firm dynamics than family support such as family expectations or long-term orientation and how these affect their firm performance.

Longitudinal studies can investigate the impact of changes in the lifestyles and culture along with government initiatives on Japanese women entrepreneurs over time. It would be interesting to explore how the changes encouraging more women's opportunities will affect women 
entrepreneurs in Japan in the long run. Future research could also examine the impact of Japanese women entrepreneurs on innovations. We expect that if qualified women have the opportunity to utilize their knowledge base by creating their ventures through family and external support (Chang et al. 2009), they may be the drivers of innovations in Japan.

\section{Conclusion}

Japanese women entrepreneurs play an important role in economic growth, even though the number of women entrepreneurs is decreasing. This may be due, in part, to the worldwide recession, the national economic downturn Japan has faced since the 1980s, as well as the natural disasters Japan has experienced. Although not hypothesized, through our exploratory survey we found that the majority of respondents think launching and growing a new business is not gender-related in terms of success factors, and some interesting findings emerged. Our survey revealed that single women and married women face different barriers. Marriage was the differentiating factor in the study. The meaning of time management differs depending on whether the respondent is married. For single women, time management can be an advantage as a business owner, whereas it can be a disadvantage for married women. Some single female business owners are pleased to spend time freely; on the other hand, they feel the lack of support from family. For married women, time management generally means how they manage to balance work and family. The survey results found that family support does not mean support from their parents but from their spouse and children. From these preliminary findings, marital status affects business success.

Along with psychological support, the lack of business support has been well documented (Oishi 2002; The Japanese Ministry of Economy, Trade, and Industry 2010). As Oishi (2002) enumerated, the barriers Japanese women entrepreneurs face are getting more complicated. This was also confirmed by our preliminary results that show that one of the biggest issues for women entrepreneurs is the lack of recognition of their new business. The fact that their business is often not perceived as a real business implies that Japanese women entrepreneurs are pioneers breaking new ground in society's recognition of the roles women can play and the success they can achieve. What is needed in addition to basic support for improving women's lives and their ability to achieve self-realization is job training, the opportunity to meet other women entrepreneurs, and fundamental support for household duties, including childcare (The Japanese Ministry of Economy, Trade, and Industry 2010). This would have a huge impact in improving the legitimacy and recognition of women-owned businesses by Japanese society.

Concerning financing, our results show that the percentage of women entrepreneurs who use their own savings for starting and maintaining their business operations decreases after the first year of operations, whereas the percentage of women entrepreneurs who use commercial bank loans for starting and maintaining their business operations increases after the first year of operations. Government should help women entrepreneurs particularly after they have been in 
their business for a year or more because their savings deplete or the growth plans and investments require more than the capital they are able to raise through personal savings.

Support for women-owned businesses needs to develop and be accessible in many different ways. As most women indicated they received support from their friends and private agencies, there is a strong connection between supporters and women entrepreneurs that is more than just financial. Therefore, establishing long-term support systems, both formal and informal, which includes accessibility to government and private agencies, is essential for further growth and acceptance of Japanese women entrepreneurs and their businesses as mainstream. We found that education was particularly important for nonfamily business owners, who do not have the luxury of using their family as a safety net, have to rely on other sources of support. The implication of this finding is that the government should invest in women's education, particularly higher education in business and areas identified in the survey as needing more skills, such as finance and technology. Internships should be required as well as other types of training programs.

\section{References}

Aiken, L. S., and S. G. West (1991). Multiple Regression: Testing and Interpreting Interactions. Thousand Oaks, CA: Sage.

Aldrich, H., and J. Cliff (2003). "The Pervasive Effects of Family on Entrepreneurship: Toward a Family Embeddedness Perspective,”Journal of Business Venturing 18(5), 573-596.

Allison, P. D. (1999). Logistic Regression Using the SAS System: Theory and Application. Cary, NC: SAS Institute Inc.

Anderson, A. R., S. L. Jack, and S. D. Dodd (2005). "The Role of Family Members in Entrepreneurial Networks: Beyond the Boundaries of the Family Firm," Family Business Review 18(2), 135-154.

Aronoff, C. E., and J. L. Ward (1995). "Family-Owned Businesses: A Thing of the Past or a Model for the Future?" Family Business Review 8(2), 121-130.

Arregle, J. L., M. A. Hitt, D. G. Sirmon, and P. Very (2007). “The Development of Organizational Social Capital: Attributes of Family Firms," Journal of Management Studies 44(1), 73-95.

Baron, R. M., and D. A. Kenny (1986). "The Moderator-Mediator Variable Distinction in Social Psychological Research: Conceptual, Strategic, and Statistical Considerations," Journal of Personality and Social Psychology 51(6), 1173-1182.

Baughn, C. C., B. L. Chua, and K. E. Neupert (2006). "The Normative Context for Women's Participation in Entrepreneurship: A Multicountry Study," Entrepreneurship Theory and Practice 30(5), 687-708. 
Becker, T. E., and R. J. Vance (1993). “Construct Validity of Three Types of Organizational Citizenship Behavior: An Illustration of the Direct Product Model with Refinements," Journal of Management 19(3), 663-682.

Brown, C. G., and N. Oakland (2007). "Women Entrepreneurship: There Are Indications of Global in Venture Business in Japan," from https://mailattachment.googleusercontent.com/attachment/?ui=2\&ik=b1d2fd9746\&view=att\&th=135baa5ef 48b10ee\&attid=0.2\&disp=inline\&realattid=f_gz4c4gvr1\&safe=1\&zw\&saduie=AG9B_PkJvhMa-cRbRZH41M_bl25\&sadet=1335055791654\&sads=UJGIZ5p8a0XDFnsP0qQ8sdQ2Lk\&sadssc=1. (accessed on April 21, 2012).

Brush, C. G., N. M. Carter, E. J. Gatewood, P. G. Greene, and M. M. Hart (2010). Women Entrepreneurs and the Global Environment for Growth. Boston, MA: Edward Elgar Publishing, Inc.

Carter, N. M. , C. Henry , B. O. Cinneide, and K. Johnston (Eds.) (2007). Female Entrepreneurship Implications for Education, Training and Policy. London: Routledge.

Chang, E. P. C., E. Memili, J. J. Chrisman, F. W. Kellermanns, and J. H. Chua (2009). "Family Social Capital, Venture Preparedness, and Start-Up Decisions," Family Business Review 22(3), 279-292.

Chang, E. P. C., E. Memili, J. J. Chrisman, and D. H. B. Welsh (Forthcoming). "What Can Drive Successful Entrepreneurial Firms? An Analysis of the Inc 500 Companies," Journal of Small Business Strategy 22(2), 27-49.

Chrisman, J. J., J. H. Chua, and L. Steier (2005). "Sources and Consequences of Distinctive Familiness: An Introduction,"Entrepreneurship Theory and Practice 29(3), 237-247.

Chung, J. (2012). "Boomers Who Start Businesses: The Next Great Generation of Entrepreneurs," Huffington Post. Fromhttp://wadhwa.com/2012/01/08/from-huffington-postboomers-who-start-businesses-the-next-great-generation-of-entrepreneurs/(accessed April 24, 2012).

Cropanzano, R., D. E. Rupp, and Z. S. Byrne (2003). “The Relationship of Emotional Exhaustion to Work Attitudes, Job Performance, and Organizational Citizenship Behaviors," Journal of Applied Psychology 88(1), 160-169.

Dyer, W. G. (2003). "The Family: The Missing Variable in Organizational Research," Entrepreneurship Theory and Practice 27(4),401-416.

Dyer, W. G., and W. Handler (1994). "Entrepreneurship and Family Business: Exploring the Connections," Entrepreneurship Theory and Practice 19(1), 71-84.

Fulford, B. (2004a). "Daring-Do," Forbes Global 7(22), 60. 
Fulford, B. (2004b). "Dressing for Kajuaru Fridays," Forbes Global 7(10), 44.

Futagami, S., and M. M. Helms (2009). "Emerging Female Entrepreneurship in Japan: A Case Study of Digimom Workers,"Thunderbird International Business Review 51(1), 71-84.

Glackin, C. E. (2002). "What Does It Take to Borrow? A Framework for Analysis," Journal of Microfinance/ESR Review 4(1), 115-135.

Greene, P. G., C. G. Brush, M. M. Hart, and P. Saparito (2001). "Patterns of Venture Capital Funding: Is Gender a Factor?" Venture Capital 3(1), 63-83.

Greve, A., and J. W. Salaff (2003). "Social Networks and Entrepreneurship," Entrepreneurship Theory and Practice 27(1), 1-23.

Habbershon, T. G., and M. Williams (1999). "A Resource-Based Framework for Assessing the Strategic Advantage of Family Firms,"Family Business Review 12(1), 1-25.

Habbershon, T. G., M. Williams, and I. C. MacMillan (2003). “A Unified Systems Perspective of Family Firm Performance,” Journal of Business Venturing 18(4), 451-465.

Hadary, S. G. (2010). "Why Are Women-Owned Firms Smaller than Men-Owned Ones?"http://online.wsj.com/news/articles/SB10001424052748704688604575125543191609632 ?mod=WSJ_hpp_MIDDLENexttoWhatsNewsTop\&mg=reno64wsj\&url=http\%3A\%2F\%2Fonline.wsj.com\%2Farticle\%2FSB1000142405274870468860457512 5543191609632.html\%3Fmod\%3DWSJ_hpp_MIDDLENexttoWhatsNewsTop(accessed January $15,2014)$.

Hall, J. R. (2004, December 20). "Women and the Family HVACR Business," Air Conditioning, Heating \& Refrigeration News 223(16),18.

Hinz, C. (2004). "Women Beyond the Pale: Marital 'Misfits and Outcasts' Among Japanese Women Entrepreneurs,” Women's Studies33(4), 453-479.

Hisrich, R. D., K. Bowser, and L. S. Smarsh (2006). "Women Entrepreneurs in Ukraine," International Journal of Entrepreneurship and Small Business 3(2), 207-221.

Hoffman, J., M. Hoelscher, and R. Sorenson (2006). "Achieving Sustained Competitive Advantage: A Family Capital Theory," Family Business Review 19(2), 135-145.

Hofstede, G. (2001). Culture's Consequences: Comparing Values, Behaviors, Institutions and Organizations across Nations.Thousand Oaks, CA: Sage Publications.

Hughes, K. D., J. E. Jennings, C. Brush, S. Carter, and F. Welter (2012). "Extending Women's Entrepreneurship Research in New Directions," Entrepreneurship Theory and Practice 36(3), 429-442. 
Hutcheson, J., and M. Zimmerman (2007). "He Led, She Led: Gender in the Family Biz,” Businessweek Online, 19.

Jordan, M. (2004, March 11). "A Family Fights over the Future of Goya Foods," Wall Street Journal, pp. B1-B8.

Karra, N., P. Tracey, and N. Phillips (2006). "Altruism and Agency in the Family Firm: Exploring the Role of Family, Kinship, and Ethnicity," Entrepreneurship Theory and Practice 30, 861-877.

Kelly, D. J., C. G. Brush, P. G. Greene, and Y. Litovsky (2011). "Global Entrepreneurship Monitor 2010 Women's Report,"

fromhttp://www.gemconsortium.org/docs/download/ 768 (accessed April 21, 2012).

Leon, S. (2012). "Sky's the Limit," Forbes Asia 8(3), 56-59.

Leung, A. (2011). "Motherhood and Entrepreneurship: Gender Role Identity as a Resource," International Journal of Gender and Entrepreneurship 3(3), 254-264.

Memili, E., T. M. Zellweger, and H. Fang Forthcoming (2013) "The Determinants of Family Owners-Managers' Affective Organizational Commitment," Family Relations Family Business Special Issue. 62(3), 443-456.

Minniti, M., and W. D. Bygrave (1999). "The Microfoundations of Entrepreneurship," Entrepreneurship Theory and Practice 23(4),41-52.

Moore, D. P., and E. H. Buttner (1997). Women Entrepreneurs: Moving Beyond the Glass Ceiling. Thousand Oaks, CA: Sage Publications, Inc.

Murphy, C., R. Bajpai, A. Fung, J. Guyon, P. Hjelt, C. Kano, and R. Tomlinson (2003). "Family Ties," Fortune 148(8), 113-114.

Ohe, T., S. Honjo, and I. C. Macmillan (1990). "Japanese Entrepreneurs and Corporate Managers: A Comparison,” Journal of Business Venturing 5(3), 163-176.

Oishi, T. (2002). "Syakai Seido No Henka to Josei Kigyoka—Josei Koyo Rodosha Tono Taihi Kara Miru [Change of Social System and Women Entrepreneurs-Comparing to Women Employees]," Chosakiho 62, 45-64.

Pearson, A. W., J. C. Carr, and J. C. Shaw (2008). "Toward a Theory of Familiness: A Social Capital Perspective," Entrepreneurship Theory and Practice 32(6), 949-969.

Pflanz, S. E., and A. D. Ogle (2006). "Job Stress, Depression, Work Performance, and Perceptions of Supervisors in Military Personnel," Military Medicine 171(9), 861-865. 
Pope, H. (2002, January 2). "For Saudi Women, Running a Business Is a Veiled Initiative-In a Nation of the Strictest Islam, Discretion Is the Vital Trait in a Female Entrepreneur," Wall Street Journal, p. A1.

Rutherford, M. W. and D. T. Holt (2007). “Corporate Entrepreneurship: An Empirical Look at the Innovativeness Dimension and Its Antecedents," Journal of Organizational Change Management, 20(3), 429-446.

Schoenberger, C. R. (2008). “Queen of Mobile,” Forbes Asia 4(9), 32-34.

Sciascia, S., P. Mazzola, J. H. Astrachan, and T. M. Pieper (2012). "The Role of Family Ownership in International Entrepreneurship: Exploring Nonlinear Effects," Small Business Economics 38(1), 15-31.

Shapero, A., and L. Sokol (1982). "Social Dimensions of Entrepreneurship," in Encyclopedia of Entrepreneurship. Eds. C. A. Kent, D. L. Sexton and K. H. Vesper . Englewood Cliffs, NJ: Prentice-Hall, 72-90.

Sharma, P. (2008). "Commentary: Familiness: Capital Stocks and Flows between Family and Business,” Entrepreneurship Theory and Practice 32(6), 971-977.

Smith, G. D. (2009). "East Africa: Extended Families with Many Rights,” Entrepreneurship Theory and Practice 33(6), 1239-1244.

Steier, L. (2003). "Variants of Agency Contracts in Family-Financed Ventures as a Continuum of Familial Altruistic and Market Rationalities," Journal of Business Venturing 18(5), 597-618.

Steier, L. P., J. H. Chua, and J. J. Chrisman (2009). "Embeddedness Perspectives of Economic Action within Family Firms,"Entrepreneurship Theory and Practice 33(6), 1157-1167.

Stewart, W. H., R. C. May, and A. Kalia (2008). "Environmental Perceptions and Scanning in the United States and India: Convergence in Entrepreneurial Information Seeking?," Entrepreneurship Theory and Practice 32(1), 83-106.

Sugihara, Y., and E. Katsurada (2002). "Gender Role Development in Japanese Culture: Diminishing Gender Role Differences in a Contemporary Society," Sex Roles 47(9-10), 443452.

Sundaramurthy, C., and G. E. Kreiner (2008). "Governing by Managing Identity Boundaries: The Case of Family Business,"Entrepreneurship Theory and Practice 32(3), 415-437.

Takahashi, T. (2002). "Josei Kigyoka No Genjo to Keieiteki Tokucho. [Characteristics of Current Women Entrepreneurs]," Chosakiho60, 1-20. 
Tamura, M. (2002). “Josei Entrepreneur No Genjou to Shorai Tenbou," http://www.gpcgifu.or.jp/chousa/infomag/gifu/107/ronbun1.htm (accessed April 21, 2012).

Teixeira, C. (2001). "Community Resources and Opportunities in Ethnic Economies: A Case Study of Portuguese and Black Entrepreneurs in Toronto," Urban Studies 38, 2055-2078.

The Japanese Ministry of Economy, Trade, and Industry (2010). "The Annual Report on Japanese Women Entrepreneurs,"

fromhttp://www.meti.go.jp/policy/newbusiness/h22fyjoseikigyouka.pdf\#search='女性起業報告 ' (accessed April 21, 2012).

The Japanese Ministry of Health, Labour and Welfare (2010). "The Annual Report on Working Women," fromhttp://www.mhlw.go.jp/bunya/koyoukintou/josei-jitsujo/10.html (accessed April 21, 2012).

The Japanese Ministry of Internal Affairs and Communications (2007). "The Report on Employment Structure," fromhttp://www.stat.go.jp/data/shugyou/2007/index.htm (accessed April 21, 2012).

The World Bank (2012). "Gender Equality and Development,” Washington, DC.

Uzzi, B. (1996). "The Sources and Consequences of Embeddedness for the Economic Performance of Organizations: The Network Effect," American Sociological Review 61(4), 674698.

Uzzi, B. (1997). "Social Structure and Competition in Interfirm Networks: The Paradox of Embeddedness," Administrative Science Quarterly 42(1), 35-67.

Welsh, D. H. B. (2012). "Women Entrepreneurs and Pathways to Success: Worldwide Results with Implications for the Economic Commission for Europe (ECE) Region," Keynote address at the U.N. Conference on Gender and Entrepreneurship, Baku, Azerbaijan, November.

Welsh, D. H. B., and E. Memili (2012). A Comparison of Women Entrepreneurs in Sudan, Saudi Arabia, Japan, and Romania. Presentation at the Bryan School of Business Administration \& Economics, Greensboro, NC, November.

Welter, F. (2011). "Contextualizing Entrepreneurship —Conceptual Challenges and Ways Forward," Entrepreneurship Theory and Practice 35(1), 165-184.

Woman-Owned Family Business Found Not Only Growing, But Better Managed (2003). Insurance Advocate 114(33), 45.

Women to Watch (A Special Report); the Owners. (2004, November 8) Wall Street Journal, pp. R1-R9. 
Zahra, S. A. (2007). "Contextualizing Theory Building in Entrepreneurship Research," Journal of Business Venturing 22(3), 443-452.

\section{Appendix}

QUESTIONNAIRE: JAPANESE WOMEN ENTREPRENEURS: A GROWING ECONOMIC SEGMENT*

1. Are you now a principal in a business? Yes $\square$ No $\square$ Previous

2. For how many years has (had) the business been in operation?

Less than 1 year.

1 to 2 years

3 to 5 years.

Longer than 5 years

3. If you are no longer in business, what was the prime reason for terminating your involvement?

Excessive time involvement.........

Lack of business growth

Family pressure.

Other: Please explain:

4. What percent of the business do (did) you own?

50 percent or less

51 percent or more

5. How would you describe the major area of the business activity?

Beauty salon Direct sales

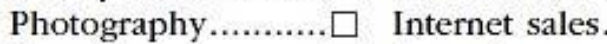

Drawing

Importing

Publishing

Exporting

Tailoring...

Accounting

Designing............... $\square$ Health care....

Other services: (please specify):

Hand Crafts.

Legal services

Food.

Childcare.

Cleaning.

Technology \& Programming.

6. How did you become a principal of the business?

Started business alone

Started business with my spouse. Started with another fam. member... Started with a non-family member.... Bought the bus. from fam. member. .
Bought bus. from a non-family member. Inherited business from a family member Inherited the business from a spouse. Other: Please explain: 
7. Please check $(\checkmark)$ the following items to describe how you obtained and maintained the funding and financing required to initiate and maintain the ownership of your business. Check as many boxes as apply.

\begin{tabular}{|l|l|l|l|l|}
\hline Source of Funding & $\begin{array}{c}\text { Initially or } \\
\text { during the first } \\
\text { six months of } \\
\text { operations }\end{array}$ & $\begin{array}{c}\text { Between the } \\
\text { first six months } \\
\text { and first year } \\
\text { of operations }\end{array}$ & $\begin{array}{c}\text { Between the } \\
\text { first and third } \\
\text { years of } \\
\text { operations }\end{array}$ & $\begin{array}{c}\text { After three } \\
\text { years in } \\
\text { business }\end{array}$ \\
\hline Own savings & & & & \\
\hline Family borrowing & & & & \\
\hline Borrowing from friends & & & & \\
\hline Government program & & & & \\
\hline Commercial bank loan & & & & \\
\hline Investment bank loan & & & & \\
\hline Gift & & & & \\
\hline Other:Please specify: & & & & \\
\hline
\end{tabular}

8. Do you feel that you had greater problems in obtaining funds for your business than a male would have had in the same position? Yes $\square$ No $\square$ Please explain:

If you feel that you had greater problems than a male, please indicate ways you overcame these difficulties.

9. Please complete the following if you received any support or/and assistant services from a government or private agencies: (please fill out as many as apply)

Name of agency:

Type of support:

Type of agency: Private

Government

Satisfaction Ratings:

\begin{tabular}{|c|l|l|l|l|l|}
\hline & $\begin{array}{c}\text { Very } \\
\text { Dissatisfied }\end{array}$ & $\begin{array}{c}\text { Somewhat } \\
\text { Dissatisfied }\end{array}$ & Neutral & $\begin{array}{c}\text { Somewhat } \\
\text { Satisfied }\end{array}$ & $\begin{array}{c}\text { Very } \\
\text { Satisfied }\end{array}$ \\
\hline $\begin{array}{c}\text { Type of support or/and } \\
\text { service }\end{array}$ & & & & & \\
\hline Amount received & & & & & \\
\hline $\begin{array}{c}\text { Manner in which was } \\
\text { received }\end{array}$ & & & & & \\
\hline $\begin{array}{c}\text { Attitude toward you as } \\
\text { a client }\end{array}$ & & & & & \\
\hline $\begin{array}{l}\text { Quality of material } \\
\text { received }\end{array}$ & & & & & \\
\hline
\end{tabular}

Name of agency:

Type of support:

Type of agency: Private

Government 
Satisfaction Ratings:

\begin{tabular}{|l|l|l|l|l|l|}
\hline & $\begin{array}{c}\text { Very } \\
\text { Dissatisfied }\end{array}$ & $\begin{array}{c}\text { Somewhat } \\
\text { Dissatisfied }\end{array}$ & Neutral & $\begin{array}{c}\text { Somewhat } \\
\text { Satisfied }\end{array}$ & $\begin{array}{c}\text { Very } \\
\text { Satisfied }\end{array}$ \\
\hline $\begin{array}{c}\text { Type of support or/and } \\
\text { service }\end{array}$ & & & & & \\
\hline Amount received & & & & & \\
\hline $\begin{array}{c}\text { Manner in which was } \\
\text { received }\end{array}$ & & & & & \\
\hline $\begin{array}{c}\text { Attitude toward you as a } \\
\text { client }\end{array}$ & & & & & \\
\hline \begin{tabular}{c} 
Quality of material received \\
\hline
\end{tabular}
\end{tabular}

Name of agency:

Type of agency: Private

Government Type of support:

Satisfaction Ratings:

\begin{tabular}{|l|l|l|l|l|l|}
\hline & $\begin{array}{c}\text { Very } \\
\text { Dissatisfied }\end{array}$ & $\begin{array}{c}\text { Somewhat } \\
\text { Dissatisfied }\end{array}$ & Neutral & $\begin{array}{c}\text { Somewhat } \\
\text { Satisfied }\end{array}$ & $\begin{array}{c}\text { Very } \\
\text { Satisfied }\end{array}$ \\
\hline $\begin{array}{c}\text { Type of support or/and } \\
\text { service }\end{array}$ & & & & & \\
\hline Amount received & & & & & \\
\hline $\begin{array}{c}\text { Manner in which was } \\
\text { received }\end{array}$ & & & & & \\
\hline $\begin{array}{c}\text { Attitude toward you as a } \\
\text { client }\end{array}$ & & & & & \\
\hline $\begin{array}{c}\text { Quality of material } \\
\text { received }\end{array}$ & & & & & \\
\hline
\end{tabular}

10. How many full-time/part-time and family employees does your business have? full time part time

family

11. What was the scope of your business geographically at start-up and what is it presently?

Local (city or county)

Start-up

Current

Neighboring cities

Province

National

International

12. Who does the planning function in your organization?

13. What type of business planning is practiced in your business?

Annual budget

Long range

According to demand

Seasonal
Other: 
14. What has been the biggest obstacle in running your business and how have you overcome it?

15. Who has been your biggest moral supporter in your business venture? Please rank in order of importance ( 1 being most important and 4 least important, leave empty what is not applicable)

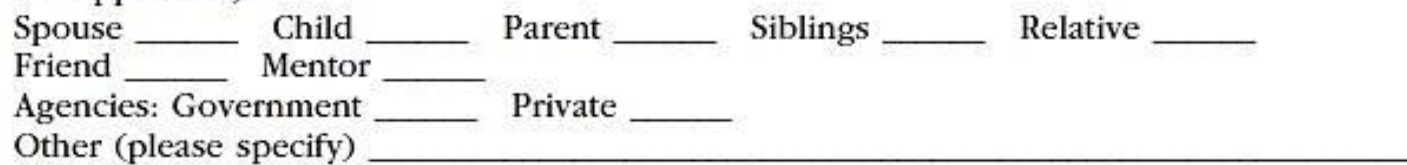

16. What support groups and/or networks have aided you in your business venture? (check all that apply)

Women's professional groups

Community organizations Social group

Other (please specify)

17. Please rate yourself on the following management skills:

\begin{tabular}{|l|l|l|l|l|l|}
\hline Skills & Poor & Fair & Good & Excellent & N/A \\
\hline Financial & & & & & \\
\hline Dealing with people & & & & & \\
\hline Marketing & & & & & \\
\hline Sales & & & & & \\
\hline Idea Generation/Product Innovation & & & & & \\
\hline Organization and Planning & & & & & \\
\hline General Management & & & & & \\
\hline
\end{tabular}

18. Your age: Under $20 \quad \square \quad 20-29 \quad \square \quad 30-39 \quad \square \quad 40-49 \quad \square \quad 50-59 \quad \square \quad 60$ or over

19. Your highest school grade completed:

Intermediate

High school

Diploma (2 year degree)......

Institution (technical/trade)..
A bachelor's degree.
A master's degree
A doctorates degree

area of specialization area of specialization area of specialization

20. Has your schooling been helpful in your business activities? Yes $\square$ No $\square$ If yes, what courses, or in what ways:

21. What do you feel have been your biggest personal problems during the establishment and running of your business? Please rank in order of importance ( 1 being most important and 4 least important)

Emotional stress

Family stress

Loneliness

Poor/lack of support

Influence of bus. on personal relationships
Influence of business on family relationships

Time management

Dealing with males

Dealing with drivers 
22. Please check $(\checkmark)$ the following table to indicate your work history while in school.

\begin{tabular}{|c|c|c|c|c|c|c|}
\hline & \multicolumn{2}{|c|}{ Intermediate/High School } & \multicolumn{2}{|c|}{ College } & \multicolumn{2}{|c|}{ Working } \\
\hline & $\begin{array}{c}\text { During } \\
\text { School Year }\end{array}$ & $\begin{array}{c}\text { After } \\
\text { School Year }\end{array}$ & $\begin{array}{c}\text { During } \\
\text { School Year }\end{array}$ & $\begin{array}{c}\text { After } \\
\text { School Year }\end{array}$ & During & After \\
\hline $\begin{array}{l}\text { Worked full } \\
\text { time }\end{array}$ & & & & & & \\
\hline $\begin{array}{l}\text { Worked part } \\
\text { time }\end{array}$ & & & & & & \\
\hline Did not work & & & & & & \\
\hline Not applicable & & & & & & \\
\hline
\end{tabular}

23. Are you presently:

Single.

Divorced

Married......

Separated.

Widowed

Please explain how your current status affects your business activities:

24. Please describe your work history prior to becoming a woman business owner.

\begin{tabular}{|l|l|}
\hline Years & Job Title/Position \\
\hline & \\
\hline & \\
\hline
\end{tabular}

25. Were the work experiences gained in these positions helpful in becoming a business owner? Yes $\square$ No

If yes, please explain:

26. As a business owner, please identify those areas in which you need additional skills/knowledge.

Marketing.

Purchasing.

General Management.

Interpersonal skills.

Finance.
General Services.

Technology and computers.

Language.

Other (please specify)

27. Current Annual Income

$520,000 \mathrm{JPY}$ and less

$520,001-1,380,000 \mathrm{JPY}$

$1,380,001-3,440,001$ JPY

$3,440,001-5,170,000 \mathrm{JPY}$

$5,170,001$ JPY and up 
28. Is your business a family business? Yes $\square$ No If yes, how many members in the business are: Immediate family members Relatives

29. How many generations of family members work in the business?

30. Would you be interested in a Women Entrepreneur's networking group: Yes $\square$ No

If yes, which would you prefer: Internet base

Personal

"Adapted from Hisrich, Bouser, and Smarsh, 2006 